\title{
Zootechnical study of breeding modes of Somba cattle in Benin
}

\author{
Tiropa Francis CHABI CHINA ${ }^{1,2}$, Adam Dourossimi ADENILE ${ }^{1,2}$, \\ Sanni-Yô DOKO ALLOU ${ }^{4}$, Pascal Abiodoun OLOUNLADE ${ }^{2,3,5^{*} \text {, }}$ \\ Mawulé Sylvie Ghislaine HOUNZANGBE-ADOTE ${ }^{1,2}$, François A. ABIOLA ${ }^{6}$ \\ and Sahidou SALIFOU ${ }^{6}$ \\ ${ }^{I}$ Faculté des Sciences Agronomiques, Université d'Abomey-Calavi, 01 BP 526 Cotonou, Bénin. \\ ${ }^{2}$ Laboratoire d'Ethnopharmacologie et de Santé Animale, Université d'Abomey-Calavi, \\ 01 BP: 526 Cotonou, Bénin. \\ ${ }^{3}$ Laboratoire Pluridisciplinaire, Ecole Nationale Supérieure des Sciences et Techniques Agronomiques de \\ Kétou, Université d'Agriculture de Kétou BP: 95 Kétou, Bénin. \\ ${ }^{4}$ Faculté d'Agronomie, Université de Parakou, Bénin. BP: 123, Parakou, Bénin. \\ ${ }^{5}$ Conseil Ouest et Centre Africain pour la Recherche et le Développement Agricoles, Dakar, Sénégal. \\ ${ }^{6}$ Ecole Polytechnique d'Abomey-Calavi, Université d'Abomey-Calavi, Département de Production et de Santé \\ Animale. BP: 2009 Cotonou, Bénin. \\ *Auteur correspondant, E-mail : abiodouno@yahoo.fr ; Tel.: (221) 772452865
}

\begin{abstract}
The Somba cattle (Bos Taurus brachyceros sp), located in Benin and Togo, has a severe reduction of its livestock in recent decades. The aim of this study was to determine the causes of this phenomenon, in order to propose new approaches of conservation. The study consisted of surveys with targeted farmers and cattle. The results indicate that Somba cattle are not cared for both in terms of food and health, justifying its low performance and high mortality rate. The parameters covered by the study vary from one mode of farming to another. For individual parameters, entrusted farming is more interesting. In more than $80 \%$ of the farms of this mode, age at first calving is around 36 months, whereas it is of 42 months in the home farming, and have an inter calving period of 14 months which is also less than 24 months in the second case. Demographic parameters seem more interesting than home farming. Then, the mortality rate is $13.46 \%$ in home farming against $16.61 \%$ in entrusted farming. Regarding to external factors, health monitoring is lax in both modes. Food is a great concern especially during the dry season. The absorption by zebu was often mentioned as the main cause of the decrease of Somba cattle livestock. The present study shows that high mortality due to an absence of health monitoring is the basis of the sharp decline in the number of Somba cattle. The influence of zebu is currently marginal because $96.22 \%$ of cattle at the farm level respondents are Somba breed.
\end{abstract}

(C) 2013 International Formulae Group. All rights reserved.

Keywords: Parameters, individuals, demographic, livestock, conservation, mortality.

\section{INTRODUCTION}

In the Republic of Benin, the national

cattle livestock is estimated at 1.717 .900
(MAEP/DE, 2005) with an average annual growth rate of 3\% (MP/INSAE, 2004). This 
livestock include Zebu (Bos indicus) and Taurine (Bos taurus) like Somba cattle.

Despite their potential and comparative advantage like trypanotolerance, rusticity, and good outcome reported by some authors (MINAGRA, 2002; Adanléhoussi et al., 2003), local taurine breeds are often ignored in favor of animals of large size like zebu when these animals are more sensitive to trypanosomiasis than indigenous breeds (Farougou et al., 2012). Therefore, local cattle livestock including Somba cattle is in constant decrease (Dossa, 2000; PAMRAD, 2006; Sokouri et al., 2009).

In the Republic of Benin, the Somba cattle are very affected by this decreased phenomenon. Its livestock decrease of 216.000 heads in 1986 (Saw et al., 1987) to 17.000 heads in 2006 (PAMRAD, 2006).

This study enters in a global attempt to safeguard and promote the Somba cattle breed and aim to determining the exact causes of this phenomenon, in order to propose new approaches of conservation of this cattle breed. For this reason our study consisted in zootechnical analysis of Somba cattle farming modes (home farming, and entrusted farming), through the evaluation of zootechnical parameters and externals factors, in order to throw into relief the advantages and limitations associated with each mode.

\section{MATERIALS AND METHODS}

Study site

According to Dossa (2000), the most of Somba cattle livestock (nearly 95\%) in the Republic of Benin is located in the commune of Boukombe. So, our study was conducted in this commune, Department of Atacora $\left(10^{\circ}\right.$ and $10^{\circ} 40$ 'north latitude and $0^{\circ} 75^{\prime}$ and $1^{\circ}$ 30' Longitude East). The commune of Boukombe is situated in the Sudanian zone and covers an area of $1036 \mathrm{~km}^{2}$.

\section{Method}

For each of the two farming modes identified, the information sought through this study are relative to: individual parameters such as age at first calving, inter calving period duration; demographic parameters such as herds composition according to ages and sex categories, the rate of exploitation, mortality rate, the cattle number dynamics over the last years, the reproduction management, data on external factors such as diet, and health monitoring, and the conditions for entrust animals to a cattle-breeder.

\section{Data collection}

The data were collected by investigation. 15 farmers were randomly selected from each of the 07 district of the Commune to obtain a sample of 105 farmers including 33 farmers in entrusted breeding and 72 farmers in home breeding. For these investigations, we used structured interviews with questionnaire. We conducted individual interviews with each farmer of the sample. After that, all the 15 farmers of each district were interviewed together with also other persons such as the Fulani cattle-breeders and the veterinary agents of the locality.

\section{Processing and analysis of data}

The collected data were processed and analyzed with statistical software ISTATTCF CSTAT Version2.

The variable "breeding mode" was crossed with all other variables (age at first calving, calving inter, mortality rate, believes Somba proportions of cattle, etc.). Various tests were used according to the nature of the data. For qualitative parameters, we used the test of independence $\mathrm{X}^{2}$. For this test, we examined whether the type of farming and these variables are related, and whether these variables have significant differences from one mode to another. Frequency tests were also used to analyze quantitative data with a large number of variables. These tests allowed us to highlight variations within modes. For others quantitative data, the non-parametric rank on independent samples (U-MannWhitney test) was performed. 


\section{RESULTS}

\section{Farming modes}

The home farming is the traditional method of rearing of Somba cattle. In this mode, the herds are small with an average of nine $(09 \pm 02)$ heads per farmer and its management is provided by one or more members of the household, usually children or the elderly. The animals are brought to pasture in the morning and taken home in evening for the night. Calves and sick animals are not brought to pasture. They are left in the yard, picketed and fed on site. Grazing lasts on average, eight (08) hours per day. There is no transhumance. Animals are taken home each evening during the dry season.

The animals belong to the manager. $\mathrm{He}$ has the ability to recover manure to fertilize their fields of production. It is he who has the milk.

According to the farmers, the entrusted farming has been developed for approximately three (03) decades with the advent of Fulani cattle-breeders in the region, due to the difficulties of animal conducting concurrently with field work and schooling of children.

Many farmers entrust their cattle to Fulani cattle-breeder who is responsible for ensuring the conduct, monitoring, and management of reproduction. The Fulani cattle-breeder is paid at 1000 FCFA per head of cow and 2500 FCFA per year bull's head and benefit from milk and dung. Also, when an animal is sold by the owner, the Fulani receives remuneration margin allocation from 1500 to 3000 FCFA.

Herd size is on average of twenty-eight (28) \pm 6 heads. In the morning, after milking animals calves and sick are brought to grazing by the cattle-breeder or a member of his family and returned in the evening. The grazing duration is on an average seven (07) hours. In the dry season, the herdsman can lead animals away from the house in search of fodder, but he brings them back every evening. There is therefore no movement of transhumance. But away from homes, local herds sometimes overlap transhumant herds of zebu made particularly at watering points.
The owner has the charge of all fees relating to their animals. The Fulani regularly informs the owner of various events that occur such as thefts, gestations, calves-births, disease, cases of mortality.

\section{Individual parameters \\ Age at first calving}

For both home and entrusted breeding methods, age at first calving ranged from 36 to 60 months, with an average of 42 and 36 months in home and entrusted breeding respectively (Figure 1).

\section{Inter calving}

In $80.14 \%$ of entrusted farms the inter calving period is of 14 months. Only $10.87 \%$ reported an inter calving of 18 months and $1.49 \%$ reported 24 months.

In the home farming, the majority of farms $(68.81 \%)$ indicated an inter calving period of 24 months. A proportion of $27.68 \%$ indicated 18 months. The rest of the farms of this mode reported 36 months (Figure 2).

\section{Demographic parameters \\ Cattle breeds}

About $98.44 \%$ of farmers breed Somba cattle. Other cattles (Zebu, Borgou, Metis) are present in $1.56 \%$ of herds.

In terms of proportion of each breed in the herds, $96.22 \%$ of cattle are Somba breed, Zebu $2.1 \%$, Borgou $1.07 \%$ and $0.61 \%$ for the half-breeds.

However, there are slight differences depending on the breeding modes. In entrusted breeding there are $2.74 \%$ of farmers with races other than Somba against $0.37 \%$ in home breeding. Regarding the livestock, in entrusted breeding there are $93.83 \%$ of Somba cattle and $6.17 \%$ for other races. In home breeding we have $98.61 \%$ bovine Somba against $1.39 \%$ for other races.

\section{Composition of herds}

Whatever the farming mode, herds are constituted of approximately $56 \%$ of bulls and cows. Bulls-calf and heifers represent $34.35 \%$ and $19.76 \%$ respectively for the home farms 
and entrusted farms. Calves, fewer represent $09.16 \%$ and $16.67 \%$ of herds respectively in home farms and entrusted farms (Figure 3).

\section{Gender ratio}

The gender ratio in home farms was of 4 females for 1 male, while in entrusted farms it's of 2 females for 1 male (Figure 4).

\section{Mortality rate over the last three years}

Mortality of animals during the last three years has been studied for three age groups of cattle. The average rate in home farms was $13.46 \%$, against $16.61 \%$ in entrusted farms. Calves and calf were more affectd by mortality in herds as shown in Table 1. They are followed by bulls-calf and heifers. In the three categories, the mortality rate was higher in entrusted farms.

\section{Exploitation rate over the last three years}

The exploitation rate is the proportion of animals exploited in relation to the total size of the herd. For both modes, the animals are mainly exploited for ceremonies, dowry, ritual sacrifices and to a lesser extent for sale.

The exploitation rate over the last three years has averaged $08.41 \%$ for entrusted farms against $06.89 \%$ for the home farms.

\section{Cattle number dynamics over the last years}

Figure 5 shows a downward trend of the cattle number (in the farms concerned by this study) over the past three years, and that, regarding of farming methods.

\section{The external factors \\ Management of reproduction}

In both farming modes, the couplings were at random and the calves-births were spread throughout the year.

In home farming, about $70 \%$ of breeders choose the genitors male on the basis of their good conformation. The rest is systematically castrated. This practice is not observed in entrusted mode.

\section{Health monitoring}

Whatever the type of farming, most of farmers do not use the services of vet. On average $16.20 \%$ of farmers use vet services.

In entrusted breeding the proportion of farmers who use the services of a vet is significantly higher than family's mode ( $U=$ $2.01 \mathrm{P}=0.036)$. Indeed, $21.85 \%$ of farmers in the entrusted mode, against only $10.56 \%$ in home farms use an animal health worker.

The interventions of vets concern mainly vaccination, particularly against anthrax, pasteurellosis, and contagious bovine pleuropneumonia. In addition to these interventions, hitching up animals receive trypanocidal treatment, anthelmintic treatment and vitamins.

Some breeders also use endogenous methods bases of local plants for the treatment of certain diseases. They represent $60.56 \%$ of the farmers in the entrusted mode $47.91 \%$ in home farming with an average of $54.23 \%$.

\footnotetext{
Alimentation

Natural pastures are the principal source of Somba cattle alimentation. During the dry season, these pastures dry out and it follows a fodder deficit.

The dry season fodder deficit is offset by the use of crop residues, fodder reserves and air grazing. Note that fodder reserves in question here are the tops of various legumes such as cowpea, groundnut, bambara groundnut, which are collected at harvest and stored.

Crop residues and air grazing are used by all breeders. Fodder reserves are used only in home farming and concern $69.5 \%$ of farms of this mode.

The majority of farmers do not use mineral supplements in animal feed. In entrusted farms $29.17 \%$ of the farmers give mineral supplements, against $00 \%$ in home farms.

The mineral supplement distributed is exclusively salt. The salt lick was encountered in any farm.
} 


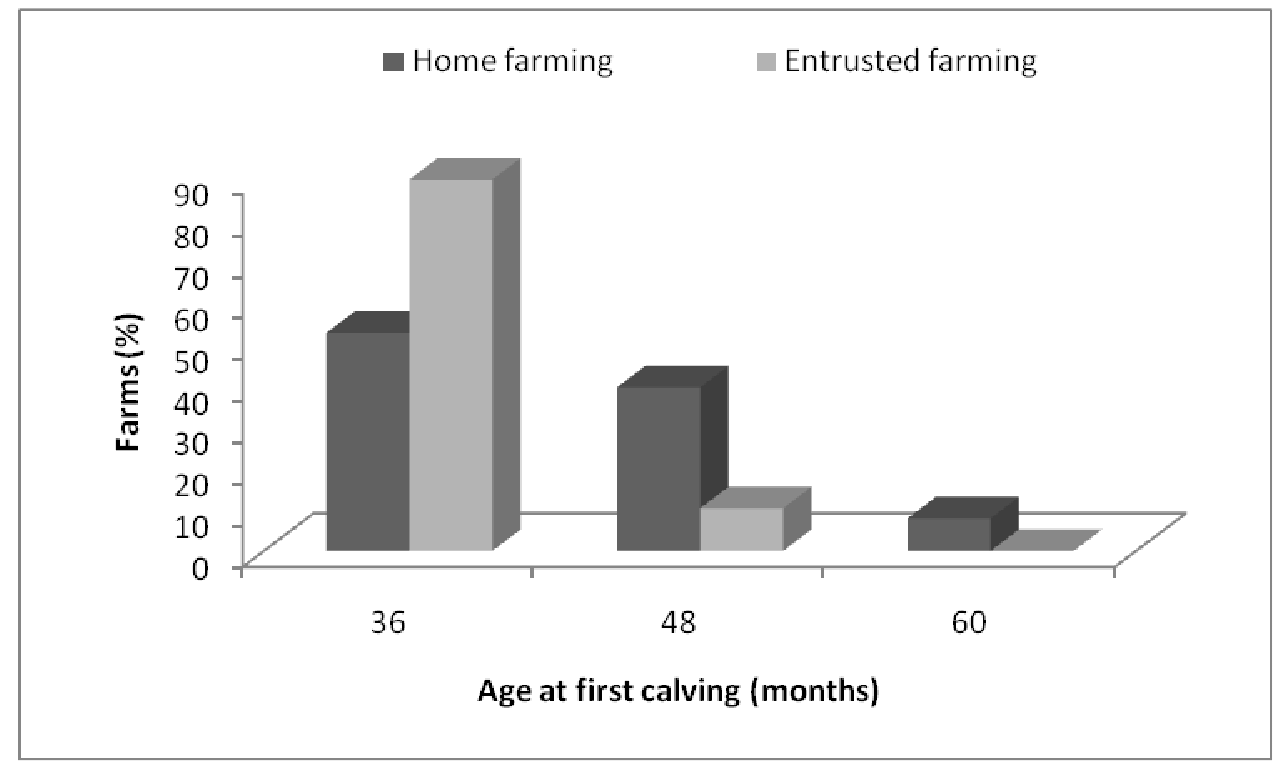

Figure 1: Ages at first calving of Somba cattle according to farming modes.

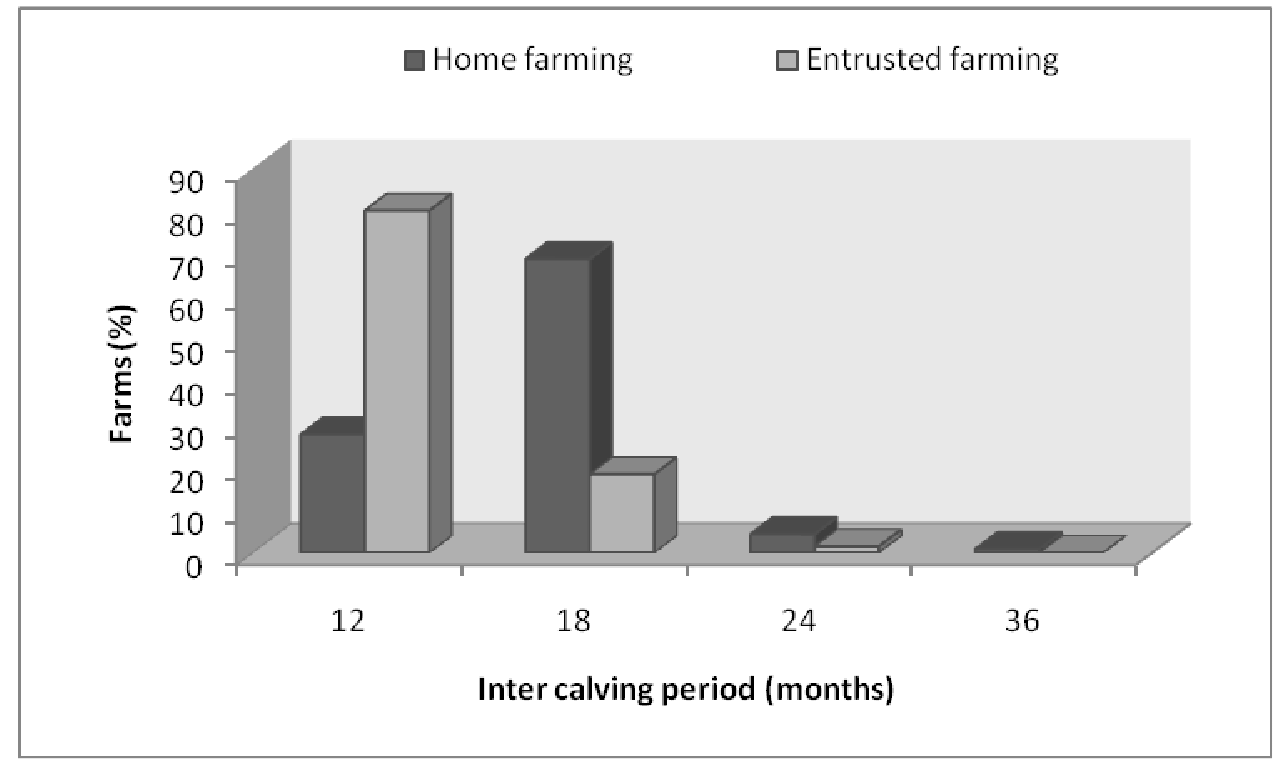

Figure 2: The inter calving period of Somba cattle according to farming modes. 


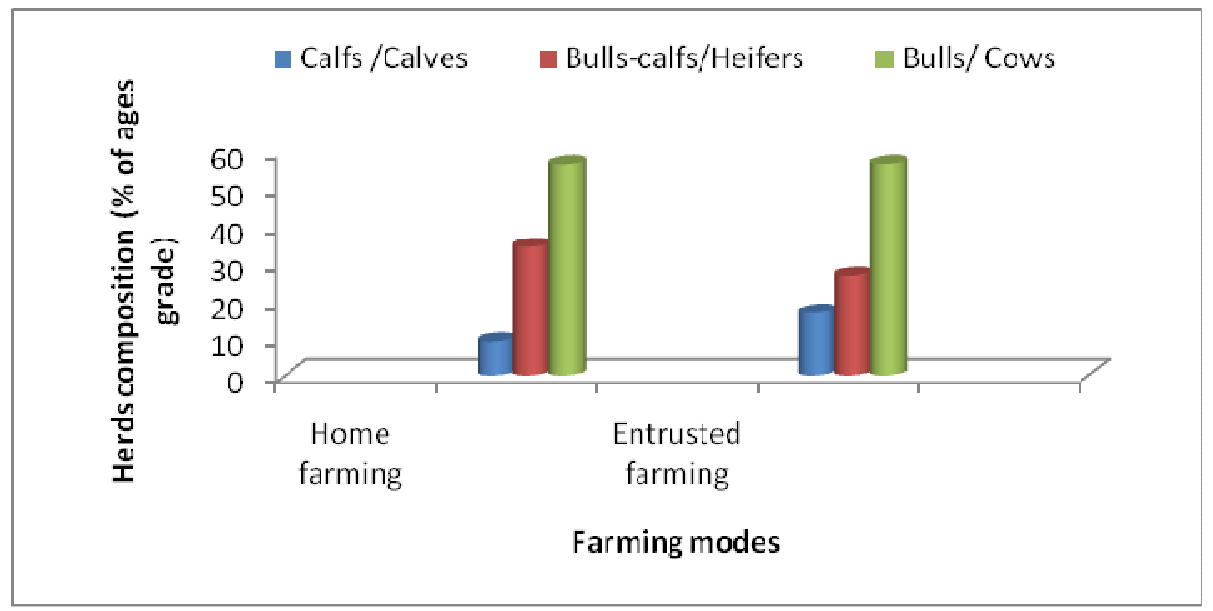

Figure 3: Composition of herds by ages grades according to farming modes.

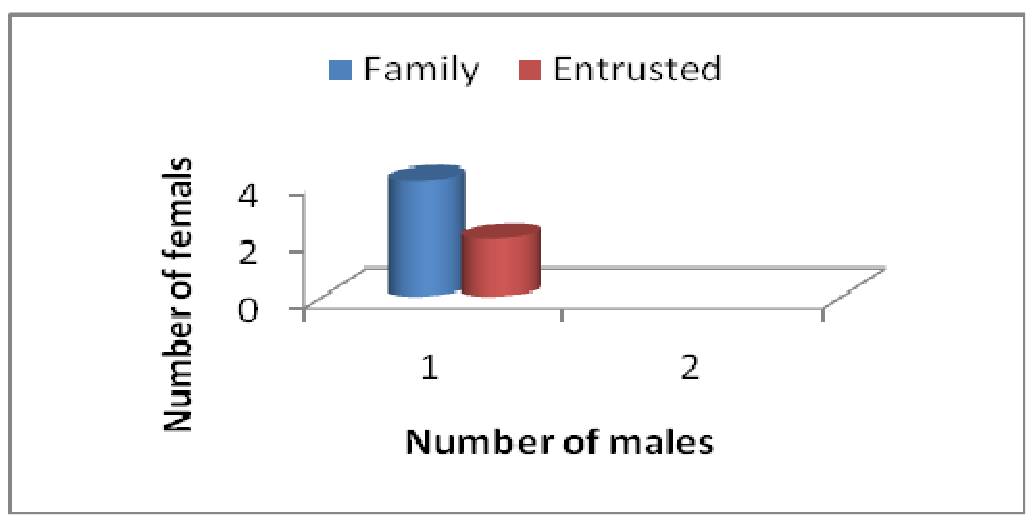

Figure 4: Sex ratio according the farming mode.

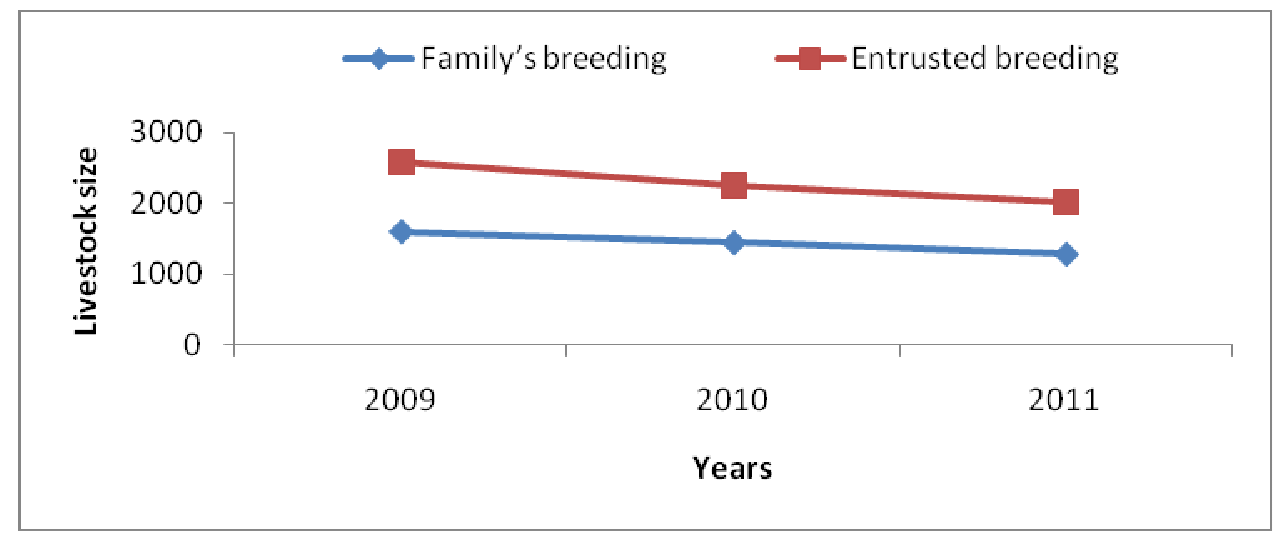

Figure 5: Dynamic of Somba cattle number in the last three years. 
Table 1: Mortality rate according age category and farming modes over the last three years.

\begin{tabular}{ccccc}
\hline & Calfs /Calves & Bulls-calfs/Heifers & Bulls/ Cows & Means \\
\hline Home farming & $20,47 \%$ & $11,39 \%$ & $8,52 \%$ & $13,46 \%$ \\
Entrusted farming & $26,20 \%$ & $13,86 \%$ & $9,77 \%$ & $16,61 \%$ \\
Means & $23,26 \%$ & $12,62 \%$ & $9,14 \%$ & $15,03 \%$ \\
\hline
\end{tabular}

\section{DISCUSSION}

\section{Individual parameters}

In entrusted breeding, cows calve precociously and the inter calving period is shorter than in home breeding. This could be explained by the permanent presence of many males in the herd promoting coupling of young females' early and short interval.

On Somba cattle in Togo, Adanléhoussi et al. (2003) found 65 months as the age at first calving and inter calving as 50 months regardless of the farming mode. These results are not consistent with our results whose are more interesting.

Working in experimental station on Borgou cattle, a local Taurine breed like Somba Adjou-Moumouni (2006) indicates a first calving age of 46 months and inter calving period of 16 months. On Borgou and $\mathrm{N}$ 'dama cattles, in experimental station too, Gbangboche and Alkoiret (2011) found a first calving age of 45 and 48 months, and inter calving period of 15 and 14 months, respectively for Borgou and n'dama cattles.

Working in villages farming on the Baoulé cattle, a Taurine morphologically close Somba cattle, Sokouri et al. (2010) indicates an age at first calving of 40 months and an inter calving of 15 months.

The results of these different authors comparated to our results show that Somba cattle, has a good reproductive performances, especially in entrusted farming.

\section{The demographic parameters}

The distribution of the herd by age group shows that in both modes the cows and bulls are the most of the flocks.

The results of the study show that the average mortality rate is quite high. It is $15.03 \%$, indicating a poor preventive health and hygiene. Younger animals are paying a heavy price. In fact, about $85 \%$ of deaths are recorded on animals 0-36 months. This high rate could explain the decrease in the number of cattle in the Somba region.

The results also indicate that the mortality rate in entrusted farming is higher than in home breeding: $16.61 \%$ against $13.46 \%$. One of the causes of mortality in calves, is the abuse of the milk at the expense of the latter being understood that the cow Somba a low milk production. The power becomes insufficient, which weakens calves and exposed to various diseases.

These results are consistent with those found by Adanléhoussi et al. (2003) on the same race in Togo. They indicate an average mortality rate of $17.64 \%$ with $47.17 \%$ of 12 24 months animals concerned.

On Borgou cattle, Adjou-Moumouni (2006) indicates a mortality rate of $2.04 \%$. On Baoule and N'dama cattles, Sokouri et al. (2010) found mortality rates of 4.15 and $1.59 \%$ respectively.

The comparison of these mortality rates with those found on Somba catllte indicate that regardless of the farming mode, the mortality is very higher in Somba cattle farming, particularly in entrusted farming.

In view of these results, we could argue that the decline of the Somba cattle breed seen for several years is largely due to the high mortality recorded each year. Thus, interbreeding indexed by Dossa (2000) as well as the rate of exploitation only plays a marginal role. The low exploitation rate $08.41 \%$ for livestock entrusted against $06.89 \%$ for livestock family) and mixing low (average $96.22 \%$ of Somba cattle breed throughout of cattle stud), support this hypothesis. 


\section{The herds' management}

The collective herds gathered at the Fulani cattle-breeder, exposed to random mating with transhumant herds during the dry season, most suffer the influence of Zebu. It is at this level that may be encountered cases of miscegenation as highlighted Moazimi et al. (2001), and Dossa (2000). In family breeding crossbreeding is rare.

Health animal practices are significantly different $(\mathrm{U}=2.01 \mathrm{P}=0.036)$. Thus, although a small proportion of overall livestock uses the services of a veterinarian, the proportion is higher in entrusted farms. Again, this is due to the group effect. Indeed, in the collective herds, when at least one owner is followed by its animal health worker, it is required of other owners to do the same. Homeowners who follow more or less rigorously the health of their animals are mostly intellectuals with a few head of cattle they entrust the Fulani cattle-breeder. The use of endogenous methods is also most important in entrusted breeding.

It should be noted that the low rate of administration of health care is one of the causes of the high mortality of cattle in the region. This high mortality contributes largely to the increasing loss of cattle in the region as mentioned above. Thus, it represents a limiting factor in the development of Somba cattle breeding.

The food problem arises with great acuity in the dry season. Livestock breeders in entrusted breeding have given record even deaths due to hunger. Indeed, in this way, given the number of livestock, harvest residues and grazing air are largely insufficient to meet the power requirements. It is the same for watering that requires travel over long distances or manual pumping.

In home breeding, the situation is less alarming. In addition, spelikans grazed grass here and there, and crop residues, animal tops benefit from different legumes produced by their owner. The contribution of vitamin and mineral supplements for animals is a practice that is uncommon in the study area. Animals who received the salt majority-owned agricultural agents or other intellectuals who entrust their animals to the Fulani. The farmer's educational low rate could therefore constitute an obstacle to improving breeding practices.

\section{Conclusion}

If the results of each parameter studied provide benefits for a mode of farming, they are however limited to give the net preference to one or the other mode. However, in order to improve farming practices of cattle, it is essential to address the shortcomings identified common and to transpose good farming practices of entrusted breeding into home breeding and vice versa.

The study also revealed that the main limiting factor that hinders the development and expansion of the Somba cattle breed is the high mortality rate in both farming modes and is mainly due to an absence of health care animals. Somba cattle ranching, responding to socio-cultural requirement that lucrative need. Since the activity is not economic, farmers are not interested to invest money to improve health monitoring and food. To this is added the fodder deficit and water especially in the dry season, and the overexploitation of milk at the expense of calves on entrusted farms to further increase mortality. The influence of crossbreeding indexed by earlier work is currently quite low.

\section{ACKNOWLEDGMENTS}

The authors wish to acknowledge MESRS/Benin for financing the study.

\section{REFERENCES}

Adanléhoussi A, Bassowa H, Défly A, Djabakou K, Adoméfa K, Kouagou NT. 2003. Les performances de la race taurine Somba en milieu paysan. Tropicultura, 21(3): 135-141

Adjou-Moumouni PFA. 2006. Evaluation des performances zootechniques des bovins de race Borgou en sélection a la ferme d'élevage de l'okpara-Benin. PhD Thesis, Cheikh-Anta-Diop University, Dakar, p.124. 
Dossa SC. 2000. Preliminary studies on the importance of ticks and tick-borne diseases inpurebred Somba in Benin. Project INCO-SOMBA, Report, p. 89

Farougou S, Doko Allou S, Sankamaho I, Codjia V. 2012. Prevalence of Trypanosome Infections in Cattle and Sheep in the Benin's West Atacora Agro-ecological zone Tropicultura, 30(3): 141-146.

Gbangboche AM, Alkoiret IT. 2011. Reproduction et production de lait des bovins de race Borgou et N'Dama au Bénin. J. Appl. Biosci., 46: 3185- 3194

Institut National de Statistiques Appliquée à l'Economie (INSAE, Benin). 2004. Principaux indicateurs sociodémographiques. http://www.gov.bj.

MINAGRA. 2002. Rapport National sur l'État des Ressources Zoo génétiques. Abidjan, Côte d'Ivoire, p.77

Ministère de l'Agriculture, de l'Elevage et de la Pèche (MAEP, BENIN). 2005. Rapport annuel d'activité 2004.Cotonou: Direction de l'élevage, p.67

Moazimi-Goudarzi K, Belemsaga DMA, Ceriotti G. 2001. Caractérisation de la race bovine Somba à l'aide de marqueurs moléculaires. Revue Elev. Méd. vét. Pays trop., 54(2): 129-138.

PAMRAD, Benin. 2006. Recensement et diagnostic de l'élevage de la race Somba dans la Commune de Boukombé. Rapport provisoire, p. 62

Projet de Promotion de l'Elevage dans l'Atacora. 1999. Projet Inco-Somba. Rapport individuel de chaque partenaire, p. 189

Shaw APM, Host, CH. 1987. Trypanotolerant Cattle and Livestock Development in West and Central Africa (Vol. 1). The International Supply and Demand for Breeding Stock (Vol. 2). Trypanotolerant Cattle in the National Livestock Economies. FAO Animal Production and Health Papers, Nos 67/1, 67/2. FAO: Rome, Italie.

Sokouri DP, Chia VY, Assanvo SPN, N'Goran EL, Brou JK, Gnénékita T, Abdourahamane S, Auguste K. 2009. Utilisation et gestion des races taurines locales sous la pression des croisements avec les zébus dans les régions Centre et Nord de la Côte d'Ivoire. J. Anim. Plant Sci., 5(2) : 456-465.

Sokouri DP, Yapi-Gnaore CV, N'guetta ASP, Loukou NE, Kouao BJ, Toure G, Kouassi Sangare A. 2010. Breeding performances of the local cattle breeds in Côte d'Ivoire. J. Appl. Biosci., 36: 23532359. 